\title{
Poetic Improvisation in the Brazilian Northeast ${ }^{1}$
}

\author{
João Miguel Sautchuk \\ Universidade Federal do Piauí
}

Pure improvisation does not exist;

nobody improvises anything from scratch

(Andoni Egaña, Basque repentista, 2005: 324).

Repente, or cantoria, is a genre of sung poetry common to Brazil's Northeast region. Its poets are called cantadores, repentistas or violeiros ${ }^{2}$. They always perform in pairs and their practice consists in a poetic dialog in which the stanzas must be composed at the time of presentation, in accord with rigid rules of meter, rhyme and thematic coherence. The cantadores alternate in the creation of stanzas over melodies that are known in advance by both, and musically accompany one another by plucking the viola. The creative effort of the singers and the appreciation of the listeners emphasize the messages of the verses, an element that requires constant creativity. Nevertheless, the music, which has previously prepared melodies (known as toadas which a type of tune), has great technical and aesthetic importance. The repentistas say that the objective is to convince the public of their superiority over their partner

1 In this article I synthesize analyses found in my doctoral thesis (Sautchuk 2009), for which I conducted field research between August 2006 - and November 2007 in the states of Ceará, Rio Grande do Norte, Paraíba and Pernambuco. Much of what I realized about the abilities and strategies of the repente is the result of my experience in practical learning of the art of the cantoria and of a modest performance as an amateur repentista.

2 Although the social field of cantoria is predominantly masculine, there are women repentistas who are known as cantadeiras or cantadoras. When I speak of "cantadores", "repentistas" or "violeiros", I am almost always referring to these women as well. They are a minority and few are able to establish themselves as professional repentistas, as a consequence of the lack of respect they receive from the male cantadores and obstacles imposed by sexual roles in this social context (especially the demands to comply with their roles as mothers and wives, and the risk of transgressing sexual morals by singing and traveling with men who are not their family. 
in poetic creation. For this reason, the cantoria establishes a dispute between the two violeiros - and is understood as such by its admirers. On the other hand, the dialogical character of the presentation and composition establishes a mutual dependence between them. Thus, the relationship between the two singers at the time of the singing is characterized simultaneously by partnership and dispute. ${ }^{3}$

As sung poetry, the cantoria has formal characteristics that are part of a special modality of verbal and linguistic expression. The regularity of the music and of the poetry constitutes a standard, a code, that carries enormous communicative power (Gonçalves 2007), and raises and intensifies the meanings of the sung messages. This is one of the essential characteristics of cantoria. The other is the improvised character of the composition, which creates a constant dialog between the poets, and between them and the audience. The idea of improvisation, of stanzas generated in the act of their oral presentation, is part of the understanding that the cantadores and their public have of the Cantoria. These are the elements that confer to the cantoria a certain enchantment and social esteem in their contexts of production. The capacity to sing improvised verses, according to the established aesthetic standards and in response to requests from the audience and movements of the partner in verse, is respected as a unique characteristic of the repentistas, and this set of attributes is understood as a divine gift that they have received.

Repente involves abilities of composition and presentation. More than techniques of poetic composition, singing and instrumental execution, these abilities concern the strategies of relationship with the other cantador, with the audience, with explicit poetic norms, with knowledge and with cognitive models. They also refer to the techniques of making music, of movement and corporal expression, as well as the ability to articulate all of these factors during a performance. The performance of these abilities establishes a relationship of the cantador with structured systems and models - such as language, poetic rules, scales and memorized melodies, social structures (above

3 Although the cantador is one of the emblems of "Northeastern culture," most Brazilians, and even many Northeasterns, have only a vague understanding of repente. Cantoria with a viola is commonly confused with the coco de embolada (which is sung in pairs, preferably at a rapid pace and with the accompaniment of pandeiros [Brazilian tambourines]) and with the written and spoken poetry of the cordel. Although they are similar, in some formal aspects, and their histories and practices are interrelated, they are distinct arts and constitute relatively autonomous fields of action, and require different abilities. 
all the oppositions of gender and social class) - in a structure specific to this activity. The art of cantoria appears, therefore, as a fertile empirical context for exploring the anthropological issue of the dialectic between models and practices, or between social structure and action. I intend to reflect on this issue, based on an ethnographic study of improvisation in repente and of the abilities of the cantador.

I follow Bourdieu's argument that actions are not a mere execution of structured models. There is a structure of practice that reproduces the structures of social life at the same time in which it has a structuring power over them. Through social experience, structures are incorporated in the form of dispositions - schemes of perception and thinking (automatically, or it could be said unconsciously applicable, but rarely explicitly as are formal principles) that allow the agents to act consistently with the logic of the social relations in questions. This is what Bourdieu calls habitus: "the socially constituted system of cognitive and motivating structures" (1977: 76).

This author affirms that the knowledge of a code provides an incomplete ability for social interactions. The meaning of the speech acts, for example, depend both on specifically linguistic elements (that concern the structure of oppositions of language as a system of signs) as well as extra-linguistic factors - context, inferences, conversational, elements of prosody, gestures etc. The interactions demand practical knowledge of a spontaneous semiology and of the ability to improvise and develop strategies, based on an immediate reading of the situations. In cantoria, there are detailed rules of rhyme, meter, and thematic coherence for poetry, but when improvising their verses, repentistas depend much more on a practical majesty, based on incorporated standards, than on explicit poetic knowledge. The analytic knowledge proposed by Bourdieu is fecund concerning the way that incorporated structures provide coherence, stability and intelligibility to people's actions, because they show the role of "practical sense" in the internalization of social reality and in the structuring of this by the action of the subjects.

Although the term "improvise" has a negative meaning (from the Latin, in = negação + provideo = anticipate, foresee, plan), the acts of improvisation, above all in music and the verbal arts, cannot be seen as random or non-systematic, neither are they characterized by an absence of information for the participants, even for the audience, about what is going to be done and heard (Magrini 1998). In music, improvisation involves a relationship between the 
musician and aesthetic styles (such as scales, rhythmic patterns, melodies), by means of which are created new results at the time the music is made) (Nettl 1974 and 1998; Sutton 1998). In poetic improvisation, there is a lot of common language, manipulation of shared traditions, of analogies of ideas and forms of construction as a creative resource, based on which the improviser is capable of constantly creating original texts (Díaz-Pimienta 2001: 173).

In addition, I understand that musical and poetic realization are products of specific cultural systems, but are also practices that create and recreate aspects of culture and of social life. Thus, music and poetry are sounds and signs after they were produced, but they are also intention and realization; emotion, idea and value, structure and form (Seeger 2004). In this sense, restricting the focus to the poetic or musical result tends to ignore the practical principles that lead to the final product. It is necessary to look at the structure and method of action - that is, at how the musical and poetic product place people in relation to each other - to learn meaning and order, not only that which is sung, but in the poetic and musical act as a whole. That is, it is necessary to understand not only how people understand things, but also how they make and experience them. I thus sought to construct an analytical strategy that does not isolate form and substance, and that allows understanding both in the context of the practice of the repente.

Therefore, it is necessary to consider more than the relationship of the improviser with aesthetic models, based on which new compositions are spun. It is important to consider the structure both of the texts (as a function of socially shared elements) as well as the collective action of improvisation. That is, improvised singing must be understood as a system of actions in which the roles performed are as or more important than the very often ephemeral result of what is done (Magrini 1998). Repente places the unknown invention of one cantador in relation with the also unanticipated response of the other, in a sequence in which the coherence is a condition of the continuity of poetic dialog. Here is an essential element of the cantoria: it intensifies the nuances and the fragility of the interactive negotiations, always in search of coherence, and emphasizes the fact that this can only be achieved in a relationship, that this context demands at least two cantadores and an audience. That is, the repente is never an individual creation, but always an interaction, in which techniques, dispositions, rules, shared knowledge and collective values are made concrete, updated, reinterpreted and reconstructed. 


\section{Cantoria: peotic models and models of action}

The classic or traditional form of presentation is the cantoria de pé-de-parede (or simply cantoria or pé-de-parede). In general, a cantoria session follows a conventional sequence and lasts for four hours. The cantadores sit in front of the public in chairs and begin to play the violas for a few minutes (at this time, a serious look on their faces indicates concentration), after which they begin to sing the poetry. The stanzas are composed and sung alternately by the two cantadores, in sequences that should maintain the same poetic modality, ${ }^{4}$ the same subject and the same tune. This sequence of stanzas is called a baião. The one who initiates a baião has the option to choose the subject, the tune and at times the modality of the stanza that will be sung. The partner must accompany these choices. To establish balance, the singers alternate beginning the baiões.

The first baiões of a cantoria are always in the mode of a Sextilha (a stanza of six verses with seven syllables), and it is customary to use them to praise the place where they are singing, known people in the audience and the promoter of that pé-de-parede; or to speak of the situation of that cantoria in an initial invitation to interaction with the audience. There are cantorias at which the audience for an entrance ticket, and others at which, in the first moments, or upon making requests, listeners place money on a tray located in front of the duo. The duo continues to choose the themes and modalities, and to take requests from the public for motes (mottos), genres and subjects upon which to improvise. After singing a few baiões, they also take requests for poems and songs, which are from a memorized repertoire, 5 returning to improvised styles to conclude the cantoria. In addition to the modalities of cantoria (improvised) and of poems and songs (memorized) there is a resource that is sporadically used and considered highly inferior - pre-composed verses presented in a simulation that they are created spontaneously. This is the so-called balaio. Isolated stanzas can be called balaios, but the term is used more frequently to refer to complete baiões that a duo

\footnotetext{
4 The different forms of stanza of cantoria are referred to as modalities, genres or styles. It is said that there are dozens of them, although many are not frequently used.

5 The poems are composed in modalities of cantoria and can be recited or sung in a toada accompanied by a viola as in the other genres of cantoria. Meanwhile the songs are compositions of the cantadores, but do not strictly follow the poetic rules of improvisation, they are composed over original melodies, and instrumental accompaniment with a variety of harmonies.
} 
uses in common agreement, or which a cantador "bota no espinhaço" (places on the back) of his colleague. In the first case, the objective of the duo is to establish a good impression before the listeners, in the second, a cantador intends to stand out before the audience as the more capable of the two.

The festivals involve another model of presentation frequently used by the cantadores. Most of these events consist in a competition between two cantadores, in which they sing pre-defined modalities and subjects proposed by the organizers, to be evaluated by a panel of judges. Here, the interaction between poets and listeners is more distant in comparison with the cantorias, both in the spatial disposition (they sing on stage, in auditoriums or in a public square) or because the audience does not make requests to the cantadores, and can only influence the poetic production with applause.

There are other contexts of presentation that have less prestige. A street market can be a place for presentation and encounter among cantadores and those who promote cantorias, but looked down upon by cantadores with higher status. Meanwhile, the performance of repente on beaches or in bars, where cantadores go to find listeners to sing verses and ask for money is a practice disdained by most cantadores, who consider it to be poetically without value and to make them look like beggars.

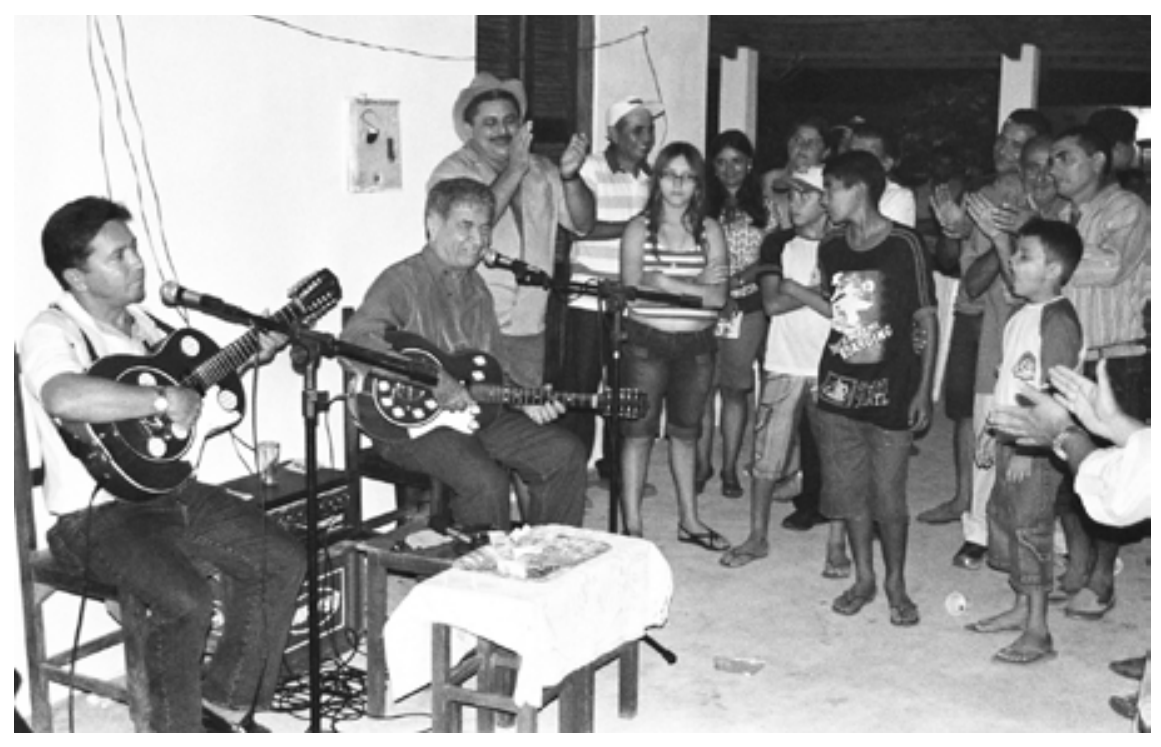

Figure 1. Close-up of a Pé-de-parede with Zé Eufrásio (left) and Geraldo Amâncio for hundreds of listeners in the metropolitan region of Fortaleza, Ceará (July 17,2007). In front are the poets, the tray in which listeners place contributions (photo: J. M. Sautchuk). 
Normally, the dispute between the cantadores is subtle and not explicit. A pé-de-parede can trigger comments from fans of one or another pointing to a winner or loser, however, it is not customary to have an obvious winner. It is common to watch one cantador not keep up with the other in one theme or genre (stuttering and delaying to conclude the stanzas) and to excel at the next. Only at festivals, in which the competition is formalized, is there an official proclamation of winners. In all of these contexts, some aspects of the challenge are encompassed by social values and principles that go beyond the social field of the cantoria. The value given to schooling as a source of legitimate knowledge reflects the respect it has as a sign of power and social status. The exhibition of "book learning" (even if superficial) is a resource for winning audience support and displaying superiority over an adversity. In addition, the very dispute of the cantoria constitutes a form of confrontation associated to standards of construction of masculinity by means of confrontation.

One of the most common ways that cantadores in the Northeast discuss their art is through explanation of the poetic norms of the cantoria. This type of prose is based on analytical and descriptive knowledge of poetry, with which the cantadores explain much of the complexity of their creation. Knowledge of the rules on its own does not provide the technique for poetic improvisation. To the contrary, this understanding usually comes to the cantador when he is already singing his repentes, in conversations with more experienced colleagues. Nevertheless, this knowledge is a form by which the cantadores translate aspects of their art. For this reason, I will provide a synthesis of the discourse about the rules of the cantoria, and later present the skills of the repentista.

It is important to note that, in the cantoria, the rules do not conflict with creativity. In jazz, for example, improvisation involves choices realized by the musicians in interaction with each other, and is understood as exploration of the new, a spontaneous action of the imagination (in contrast to a routine of individual study and practice in group characterized by repetition and discipline), based on which a musician transforms and rearranges elements of the musical tradition in new constructions (Faulkner 2006). Meanwhile, the improvisation of the cantador is not understood as an impulse of creative liberty, but as a moment of "inspiration." The cantadores see their activity as an exercise of a "divine gift" that 
allows them to participate in making poetry, following the rules considered necessary to do so. The verso grande is the stanza in which the poet presents beauty and creativity and demonstrates knowledge within the proper poetic configuration. It is a well-constructed stanza that meets all the formal requirements that give a sense of completion, perfection and surprise. Thus, the question is not to go beyond the rules, but to show an ability to create with them.

The cantadores understand that their poetry is based on three foundations: meter, rhyme and oration. The final element concerns the coherence in the creation of the verses with the themes requested by the audience or initiated by one of the poets. There should be coherence both within each stanza and throughout a baião. In practical terms, this imposition helps to maintain the intelligibility of the repentes, maintains the communication between the poets and audience and requires the singers to seek new ideas in the development of the themes proposed. In addition, it stimulates the dispute, given that a poet cannot diverge from the themes requested by the audience or initiated by the other.

Rhyme, despite the rigidity of its rules, is considered the most simple foundation, and a well-informed poet is unlikely to err in this regard. In cantoria, the rhymes should be consonant, that is there should be complete correspondence between the phonemes, from the tonic vowel to the end of the rhymed words. In addition, they should adhere to the so-called rules of proper Portuguese. Thus, one does not rhyme "mulhé" with "café", "cantấ" with "Ceará" and "cantadô" with "chegô.." "Mulher" rhymes with "quer", "café" with "Assaré", "Ceará" with "lá", "cantador" with "amor" and "chegou" with "desabou." It is considered correct to use some rhymes with words whose endings have the same sound in speech such as "Goiás" with "mais" and "capaz," and "touro" with "namoro." Nevertheless, attention must be paid to distinctions, for example, between "céu" and "menestrel" and between "ver" and "vê" ("ler" and "lê"...), which, although may be pronounced similarly in common speech, are mistakes that the more careful will not accept. There is a consensus about these rules, although their command is not equally accessible to all, because they depend, to a large degree, on a command of written language. Normally, the cantadores learn the rules of rhyme from teachings that are explained in conversations with more experienced colleagues. 
Obviously, rhyme has a rhythmic dimension (and therefore a metric one) and helps to establish standards of duration within the stanzas by means of a regulated repetition of the phonemas. "Rhyme" comes from the Latin word rhythmus and at its origin refers to controlled movement, to a regular cycle. Nevertheless, upon speaking of rhyme, the cantadores pay more attention to the restrictions than to this essential dimension of the parallelism between phonemes for the poetic discourse.

Meter concerns the rhythm and is referred to as the quantity of verses per stanza, of syllables per verse and in some cases, includes the distribution of prosodic accents within them. Each style has its own standard meter. The etymology of the word "verso" [verse] points to the idea of order of the elements that are repeated. It is not by chance that many singers consider meter the essential dimension of poetry: it is the rhythm that gives the sensation of order and perfection and confers to poetry its special status in the forms of discourse. According to Jakobson, "[in] poetry, any verbal element is converted into a figure of poetic discourse" (1975: 161). The verse, as a "figure of sound," has as the principle for the combination of its elements, parallelism and equivalence of forms (explicit in the symmetry of the verses, in the phonemic similarity of rhymes and alliterations, in the rhythm and in the redundancy of the pauses and accents). Thus, the structure of poetry is a continuous parallelism that finds correspondence in ideas and engenders semantic parallelism - rhyme, for example, constructs a relationship of meaning between words based on their acoustic similarity.

The rules of the meter of the cantoria are exposed according to the promoted principles of the accentual-syllabic system of versification in the Portuguese language, according to which the rhythmic units are divided, based on the succession of the strong and weak syllables. The syllables are counted only up to the final tonic of each verse and an elision of the vowels - the last and the first - of consecutive words can be made. Therefore, the counting of poetic syllables of a verse does not necessarily coincide with the number of grammatical syllables.

The most common modality of the cantoria is the Sextilha, with which any presentation is begun. As the cantador Zé Maria describes: 
A Sextilha é uma estrofe

Que mostra no seu contexto

Seis versos de sete sílabas

E apresenta o seu texto

Rimando o segundo verso

Com o quarto e com o sexto.

(Zé Maria de Fortaleza 2006)
The Sextilha is a stanza

That displays in its context

Six verses of seven syllables

And presents its text

Rhyming the second verse.

With the fourth and sixth

In addition, in the cantoria, the first line should accompany the deixa (the last verse sung by the other), or that is, should rhyme with the even verses of the previous stanza sung by the colleague. This imposition helps to establish poetic dialog and makes the use of memorized verses more difficult.

Other modes or genres that are quite common in cantoria include décimas, which have verses of seven, ten or eleven syllables. The ten versus always rhyme in the sequence ABBAACCDDC. With hepta-syllabic versus, there is the Mote em Sete Sílabas, or Mote em Sete [Seven Syllable Motto]. The word mote [motto] refers to a phrase, usually with two verses, with which the poets should conclude their stanzas. It also indicates the stanzas composed with a basis on these phrases. The hepta-syllabic verses (common in various forms of traditional Iberian singing) require the accent on the final syllable, but allow freedom for the disposition of strong and weak syllables throughout the verse. Meanwhile the decasyllabic and endecasyllabic have a standard of distribution for the tonic syllables. In the decasyllabic, the third, sixth and tenth syllable should be emphasized. In the endecasyllabic, the accents fall on the second, fifth, eight and eleventh syllable. ${ }^{6}$

Although we have emphasized the restrictive power of the norms and rules, they have essential positive roles. Rhyme, for example, offers a clear restriction to the development of themes, but can also create suggestions and stimulate the poet to new associations of ideas.

One of the first times that I sang repente (without an audience), the cantador Zé Maria proposed the mote "Toda passarada canta / Quando chove no sertão" [All the birds sing/when it rains in the sertão] $]^{7}$ and composed the stanza:

\footnotetext{
6 Examples of these modalities will be analyzed below.

7 The term sertão, in a broad sense, indicates the lands of the Brazilian interior, far from the coast and the large urban centers. In the Northeast, the term indicates the dryest zone, with a semi-arid climate whose colonial occupation was driven by husbandry.
} 
O camponês nordestino,

Quando não chove, tem medo.

Todo dia, acorda cedo

Preocupado com o destino.

Quase que num desatino,

Faz a sua oração,

Mas, se a chuva molha o chão,

O medo logo se espanta:

Toda passarada canta

Quando chove no sertão.
The northeastern farmer

Is scared when it doesn't rain

Wakes up early, every day

Worried about his destiny

In near folly,

Says his prayer,

But, if the rain wets the ground,

The fear is soon scared off:

All the birds sing

When it rains in the sertão.

The entire story of the stanza is a function of the association of ideas that originated with the word "espanta," [scare off] that I thought of to begin the composition due to the rhyme with "canta" [sing]. Given that the mote establishes the rain as a positive event, I thought of negative elements that would be chased by it - hunger and fear.

The rules synthesize standards of order of poetry and of actions of creating it and singing it, and this order is much of what makes the cantoria something enchanting for those who take part in it, whether as listeners or poets. The identity of the repentista is related to an ability to express oneself within this order. Thus the disdain for errors of rhyme and meter (whether in improvised verse or those written by poets of the cordel) and the detestation that many cantadores express for free verse of modern poetry.

The standards synthesized in these explicit models go beyond the domain of poetry itself. The "pegar na deixa" [pick up the rhyme from the last verse of the other] and oration impel the poetic creation to dialog, both between the cantadores as well as between them and the audience. They also have an ethical dimension (Travassos 200o), because the first inhibits the use of memorized verses, and the second makes it improper to escape the themes proposed by partners and listeners. Therefore, more than poetic formalities, these norms express ideas and judgments about the standards of interaction of making poetry.

The models of the festivals and the pés-de-parede are part of the common understanding of the cantadores and listeners about these practices. They frame perceptions and guide collectively based action that is linked to ethic and aesthetic principles. These models are both practical as well as cognitive, because they constitute frameworks that make the cantoria rituals recognizable and understandable. 
I do not mean to say that the explicitly formulated rules are the effective factor in the actions. Discourse leaves unsaid all that which takes place without the need for speech or verbalized reflection. For this reason, these norms only have complete meaning as a function of the dispositions internalized by the subjects in their social experience, which guides their perception of the world and social relations (Bourdieu 1977). In reality, a subject cannot be conscience of all the issues involved in the correct application of a rule, because the possible variations of factors are infinite (Taylor 1993: 45-6). The norms are both a body of precepts for the correct realization of the cantoria as well as a collective commentary on primordially incorporated principles of interaction, which do not depend specifically on enunciation.

The exposition of some rules and configurations of cantoria presented above served to describe aspects of poetic improvisation, concerning both poetry as well as the dynamic of the social relations of the cantoria. My description was not detailed, but will be sufficient for understanding the abilities of the repentista, which I discuss below. First, I will address musical characteristics of the cantoria.

\section{Voice and viola: the music of the cantoria}

Although the cantadores consider themselves to be poets and not musicians, music in the cantoria is simultaneously secondary and essential, both an accessory and indispensable. On one hand, some affirm that to be a "good repentista" is to be good in poetic creation; the singing and the instrumental accompaniment are "a complement," something to emphasize the poetry and the sonority of the verses (Ayala 1988: 133). In fact there are cantadores considered to be weak in the tune of their singing and their abilities with the viola. Many poets and fans emphasize the beauty of the voice and singing in tune as essential requisites for the career of a successful cantador. Some good repentistas are not pleasing to audiences and colleagues because they do not sing in tune. Therefore, fitting into certain aesthetic and musical standards is a necessity recognized by cantadores and listeners.

The toadas always correspond to the extension of a complete stanza. There is a repertorie of toadas that constitute a collective patrimony for the cantadores. The most common modalities such as the Sextilha and the Motes have a wide variety of toadas. Less executed styles, or those that are 
never sung more than once in a cantoria or festival, tend to have less toadas or only one. The toadas have recognizeable melodic designs and are sung with "reasonable fidelity to the general melodic design of specific melodic segments" (Travassos 1999: 9). There is no need to precisely reproduce the sequence of notes of a toada, in part because reference versions for these melodies do not exist. Variations in the singing of these melodies are common (including alternations of steps along the scale or an inversion of melodic movements) whether by two poets singing together, or by a single poet, during a baião (Travassos 1989: 120; Ramalho 2001: 74,81). That is, the toada is the element that is repeated, but this repetition always implies a transformation and variation.

The majority of the toadas have a descending melodic design with their final motif concluding on the keynote (Oliveira 1999: 139) to which the bordão (a set of three strings that includes the lowest string on the viola) are tuned. They are sung within an octave and are characterized by a tense and nasal vocal expression. Each verse corresponds to a melodic motif, with the verses grouped in pairs (or at times in triplets) forming melodic phrases with the final note extended, nearly always in vibrato, before the cantador takes a breath (Oliveira 1999: 128,171; Crook 2005: 105-6). That is, the toadas are composed of motifs corresponding to the verses, grouped two by two in musical phrases analogous to the phrases of the two verses that compose the stanzas.

In addition to helping maintain communication between the singers and listeners in events that usually last a few hours, the melodies contribute to the construction of the meaning of the poetic texts (Travassos 2000: 71). Changes in theme are marked by changes of toada and their melodies are informally classified according to the melodic characteristics that link them to themes by the type of feeling that they convey. Although there are no exclusive melodic characteristics that define types of toadas, some are considered "aggressive," (destined, for example to the challenges) in which the aggressive character is associated, with a high melody and strident timbre. Meanwhile "painful" toadas (suitable to sad themes such as heartbreak, longings for childhood and one's birthplace and posthumous homages), present a recurrence of the $3^{\text {rd }}$ and of the $6^{\text {th }}$ lower steps, "provoking a sensation of a lower tone" (Travassos 1989: 121-A,124).

The viola is similar to a guitar, but is a bit smaller and has more strings. The repentistas use a tuning with seven steel strings arranged in 
five orders: E, B, Gg, D and A (with the last set of three strings, the bordao, which has the same note in three octaves). The strings are quite taut, which produces a higher tessitura and a strident timbre. Usually only the thumb and index finger are used to pluck the strings. Many cantadores prefer to tune the viola a tone and a half lower, but name the strings as described above.

The instrumental accompaniament to the singing in the modalities of the repente is called baião-de-viola and consists in a repeated cycle of alternation between the chords of $A$ and $D$ major, with small variations in a particular rhythm over a pedal note (the bordão). Short melodic fragments are executed in the higher regions of the instruments. Depending on the situation, both cantadores play the violas while each one sings, one plays something to accompany the singing of the partner or does not play the viola during the singing of the stanzas - which is more common, because the principal element of presentation is the voice. In this case, they may play a chord at times to coincide with the pauses for breathing between the stanzas, and at the end of the stanza, play the baião-de-viola until the other singer begins his verses (Oliveira 1999: 98). ${ }^{8}$

The viola serves as a "tuning-fork," to tune the singing, and also as a "metronome" that guides the progress of the improvisation (Oliveira 1999: 129) and provides the rhythmic reference for the poetic dialog. A cycle of alternating chords in the baião de viola can be fit into a simple 4-4 time, equivalent to a heptasyllabic verse. The poets usually prolong the final syllable of a stanza for a cycle, even when they sing decasyllable verses. It is also the rhythm of the viola that lets the poet know when to begin singing. The most common is to "release" his verse after one, two or three cycles of the baião-de-viola. In the breathing in the middle of a stanza, or in a pause to think, this cycle, or part of it, has the phatic function of preserving the rhythm of the repente and maintaining the intensity of the communicative relationship. In the genres with seven syllables and in the Galope à Beira-Mar, the baião can be played, or variations on it, together with the singing. Meanwhile the decasyllables fit rhythmically into the composed measures (Oliveira 1999: 132,135-6), which impedes the use of the cycle of

8 In the poetic styles with a refrain, the toadas are in a major key and the accompaniment is conducted in the same tempo with the chords of A and E major minor7. 
the baião-de-viola in the musical accompaniment, which occurs in a simple four-beat measure only in the interludes between stanzas and on the breaths and occasional pauses between verses.

The baião-de-viola helps the cantadores to maintain both the poetic rhythm of each stanza, as well as the rhythm for switching stanzas with the partner. When one poet takes too long to "release" his verse, strumming the chords of the viola while he thinks about what to say, he breaks the progress of the poetic dialog and disperses the public's attention, which tends to understand that the cantador who delays is "getting whipped." Exaggerating in the opposite direction, there are poets who, in heated disputes, begin their singing as soon as the other completes his last syllable, nearly connecting his stanza with that of the other. This is also looked down upon because it inhibits or covers up possible expressions from the audience (applause, shouts, praise) for the other's stanza. The most proper, according to the ethics of the cantoria and the expectation of the listeners, is to begin singing after a pause equivalent to one, two or three verses, with the rhythm of the baião-de-viola as a guide.

The relationship of the toada with the poetic rhythm and with the construction of meanings of the texts, as well as the guiding function of the baião-de-viola indicate that the verses of the repentes should be understood in relation to the other communicative resources of the cantoria. These communicative elements formally complement each other. In the cantoria, the characteristic of the poetry to create relationships of meaning through parallels, exposed by Jakobson, go beyond the plane of the linguistic message, and this semantic creation also occurs through a "fusion" of expressive modes (Tambiah 1985), principally language and music. In the repente, there is also formal redundancy in the melody of the toadas (which provides a poetic rhythm), in the melodic characteristics that suggest moods and feelings, in repetitive harmony and in required alternation between the two cantadores in the composition of the stanzas. That is, although the linguistic content of the verses is, for many, the most important element of the repente, and meter is the primordial factor in its organization, the wealth of the cantoria is not in any one of its elements in isolation (the message, the toada, the baião-deviola...), but in the communicative form that they compose as a group. The elements of a perceived standard are ordered one in relation to the others. This order is the basis of a cohesion that gives life to these elements as a totality in the light of our capacity for perception (Kubik 1979). 


\section{Rhythm and poetry}

The simplest explicit knowledge of the rules of poetry are limited to a formal description in terms of the number of verses and syllables of the stanzas - the Sextilha, for example is classified as a stanza of six verses of seven syllables. Nevertheless, this description does not express how the cantadores create and sing the stanzas. Many repentistas say that they compose the stanzas creating the verses two by two, or that is, based on phrases of two verses (and also of three verses in some modalities). This is seen in the poetic rhythm with the prolonging of the final syllable of a phrase with two verses and with occasional pauses between two phrases. Each phrase presents an idea that participates in the construction of the message of the stanza, as in these improvisations:

\section{Ivanildo Vila Nova}

Poesia é alimento / Que é feito com verso e voz

[ 1 a frase: o que é poesia e do que é feita]

Para nutrir o espírito, / Para brilhar como os sóis.

[2․ㅡ frase: para que ela serve]

É inventada por Deus / E interpretada por nós.

[3 $3^{\text {a }}$ rase: é um dom divino dados aos poetas]

Poetry is food / That is made with verse and voice

[1st phrase: what is poetry and of what is it made]

To nurture the spirit, / To shine like the suns.

[2nd phrase: What is it for]

It is invented by God / And interpreted by us.

[3rd phrase: it is a divine gift

Given to the poets.

\section{Raulino Silva}

Transmitida pela voz, / Ela vem com segurança.

[1ำ frase: sua concretização se dá pela voz]

Pode ser vista até mesmo / No sorriso da criança,

[2 frase: manifesta-se nas coisas mais corriqueiras]

Mas, de dia para dia, / De onde vive, faz mudança.

[ $3^{\underline{a}}$ frase: caráter inefável e misterioso da poesia]

(Cantoria in Baraúna, Rio Grande do Norte, 2007).

Transmitted by voice, / It comes safely.

[1st phrase: it is made concrete by voice] 
It can even be seen / In a child's smile,

[2nd phrase: it is manifest in The most common things]

But, day by day, / Where it lives, it makes changes.

[3rd phrase: ineffable and mysterious character of poetry]

Concerning the recited verses of the cordel, Manoel Cavalcanti Proença affirms that "an examination of the intonation gives us the first composed unit, or that is, the set of two verses," making the Sextilha a "mono-rhythmic triplet" (apud Ayala 1988: 137-8). In the same sense, Ramalho (2001: 73-5) affirms that the Sextilha in cantoria is structured not in six verses of seven syllables, but in three verses of fifteen syllables, usually with a pause after the first. The toadas of Sextilhas are formed by three musical phrases corresponding to these sets of 15 syllables, but with a caesura that divides the phrases into two segments corresponding to verses with seven syllables. When some singers analyze their poetry, they recognize this unit of two verses, which can be found in other genres of cantoria and is also valid for the improvised décima in Cuba (Díaz-Pimienta 2001: 200-1).

To more precisely understand the importance of rhythm for the creation of the verses in the repente, a comparison can be made with studies about other traditions of improvised and sung poetry. Albert Lord (2000), in his study about epic poetry in the former Yugoslavia, emphasizes the speed with which the bard composed his verses - nearly 10 - 20 decasyllabic lines in a minute - and presents a deep understanding of the structure and method of performance of epic songs by these singers. Each poet-singer knows a repertoire of traditional narratives that, although they have fixed plots and personalities, are not memorized and recited, but composed at each presentation. The principal compositional device of the bard is the formula, a phrase or group of words that express the most common ideas and actions within the poetic narrative about the metric and rhythmic standards. By means of memorization of formulaic expressions, the poet gradually and unconsciously incorporates the meter of the ten syllabic verse with a pause between the fourth and the fifth, and absorbs the tendency to distribute the accents and their possible variations according to the melodic line. The command of a repertoire of formulas also provides the bard a system of substitutions of words and a sense of construction of parallelism of phonemes (rhymes and alliterations).

One of Lord's achievements was to examine the composition process 
instead of only paying attention to the recited result- the poems. For this reason, I consider his analytical tools suitable for exploring the poetic-musical abilities in repente by means of identification of systematized elements of composition (part of them unconscious) and the way that the cantador understands and perceives the units and the totality of their compositions. The theory of composition by formulas postulates the existence of cognitive standards and models used by the artist in the composition of sonorous structures and or narratives in the process of their performance. ${ }^{9}$ Inspired by these theoretical tools, Nettl (1998) and Sutton (1998) understand improvisation as composition in the course or in the act of performance, in an action that involves the interaction of the musician with a more or less fixed musical model: a melody, a rhythmic standard, a chord progression (even if not actually sounded). This model would be a starting point, a basis for the improviser, as are the formulaic expressions identified by Lord.

Evidently, the cantoria of the Brazilian Northeast has fundamental differences with the epics of the Balkans. Mainly, the bards sing as they compose verses about predefined plots in which the use of the formula constitutes precisely the repetition and variation of expressions that are aggregated to these narratives. For the repentista, a repetition of words or entire lines would be a gross error. Another reservation that should be raised in relation to use of the concept of formula for understanding the method of the cantador refers to the varied themes of the verses in this context, which impede the identification of lines that in the epic poems are systematically substituted or rearranged in the act of retelling a story. Similar warnings are raised by White (2005: 266) in his analysis of the bertso of the Basque improvisational poets.

The concept of formula serves as an inspiration to understanding the relationship between rhythm and word in the construction of the poetic improvisation of the cantoria. The Northeastern cantador composes his verses by following rhythmic standards expressed not in recurring phrases, but in the toadas, in the melodies. Raulino Silva, a young cantador, once told me that the toada is like a form of cutting dough to make pastry, which can be understood to mean that it allows the generation of regular and homogenous

9 Lord is criticized (Nettl 1998; Finnegan 1988) for establishing a dichotomy between orality and writing - which was exacerbated by many of his followers - and for defending that his conclusion about the epic Yugoslavian songs is universal to all forms of oral poetry. I agree with the content of these criticisms and do not intend to repeat these inconsistencies. 
sonorous substances. He affirmed that most of the cantadores have command of concepts of versification.

But no one uses this [when singing], no one counts syllables to make a stanza. We create meter with the toada, by the rhythm of the music that we sing. We chose the word and know that that word did not work because it does "not give a rhythm," does not give a rhythm while you sing. So, all the cantadores use this mode of creating meter. Even those most tied to this technical business know that one thing rhymes with another, and the first rhymes with the second and the third rhymes with any old thing. Even they use this form of creating meter: by the toada, by the rhythm. Because, when you use a word that "does not give rhythm", you know it.

In the same sense, other poets told me that to sing repente is like "filling" a recipient: when you "lose the meter," you realize that there was not enough or too much content; that based on the toada, you "fill in with the phrases and don't let them go beyond or not be enough"; or that an error in meter "breaks the musicality of the repente." That is, it is the rhythmic standard contained in the toada that guides the singers when composing the verses within the pre-established metric standards. The quantitative metaphors of form and recipients add to the understanding of meter as something tied to musicality. An error in meter is perceived by the ear as a lack or excess of musical quantities, because the verses have a fixed quantity of syllables that correspond to musical tempos while the linguistic accents coincide with accents of melodic rhythm (Oliveira 1999: 132).

The same idea is relevant for other traditions of repentismo. The Cuban repentista Aléxis Díaz-Pimienta considers the tonada to be the "unsuspected, psychological mold for the improvised text" (2001: 200). For the Basque bertsolari, the melody governs the creation of the verse: the meter adjusts to the melody, which is the fixed part of the song, while the words change (White 2005: 269). Like the singers of the Brazilian Northeast, these poets do not count syllables when they improvise, because they base themselves on a correspondence between melody and meter. Singing that does not force the melody respects the meter. If a portion of the melody is abbreviated or prolonged, it is clear that this essential element was not executed with perfection (Egaña 2005: 325-6). In cantoria, as well as in these other traditions of sung and improvised verse, the toadas, memorized elements, serve as a type of formula, guiding 
the composition of the verses, to the degree that the melodic designs fit the meter structure of the stanza and allow its internalization and its use without the need for a conscious counting of syllables and lines.

As a "mold," the toadas of the cantoria indicate more than the quantity of poetic syllables (corresponding to pulses) of each line. The Sextilha, like the other modalities of verses of seven syllables, does not have a fixed distribution of accents within the lines. The only required accent is that of the seventh syllable. Their toadas are melodic motifs that coincide with the poetic lines. According to Oliveira (1999), these motifs are composed of eight musical pulses, with a merger of the last two pulses in the acute verses or with the last one corresponding to the final syllable of a paroxytone in a "low verse", and the last two syllables in the proparoxytone verses. ${ }^{10}$ These motifs are grouped in pairs that form phrases. Nevertheless, the tunes of a Sextilha are formed by three phrases of two motifs, analogous to the structure of the stanzas in three phrases of two lines. The final motifs of each phrase are often the same, repeated or transposed one step below in the scale. These motifs correspond to the paired lines of the stanza, which rhyme with each other, which forms a parallel between repetition (or similarity) on the plane of the phonemes and on the plane of the melody. This correspondence between phonological similarities and melodic similarities is not as systematic in all the genres of cantoria, but it nevertheless assists in the composition of the verses, informing the sequence of rhymes of each modality.

In the modalities of 10 and 11 syllables, there is a fixed disposition of the accents in the verses. The toadas musically mark these accents. In the decasyllabic verses like the Mote in 10 and the Martelo Agalopado, the accents fall on the third, sixth and tenth syllables or pulses of each verse, as in this improvisation by Jonas Bezerra over a mote (the tonic syllables are in bold).

Não confundo o amor com aparência,

Que o amor possui uma plenitude.

O conceito de mãe não tem quem mude:

Uma flor que transcende a inocência.

10 "Sharp" [agudo] verses are those that end in oxytones; and "low" [grave] verses end in paroxytones. This denomination is found in grammar books and manuals of verse and some cantadores use it. The proparoxytone verses are known as esdrúxulos in Port. 
O amor sempre tá na presidência,

Mas não bota o seu nome em eleição.

Não tem urna fazendo apuração

Nem ninguém procurando ser suplente.

O Amor é o único presidente

Que governa o país do coração

I don't confuse love with appearance

Love has completeness

The concept of mother no one can change:

A flower that transcends innocence.

Love is always in the presidency,

But doesn't put its name up for election.

There is no ballot box being checked

Or anyone looking to be an alternate.

Love is the only president

Who governs the country of the heart

Each verse is divided in three parts that respectively culminate in the accents of the third ("O concei-"), sixty ("-to de mãe-") and tenth syllables ("não tem quem mude"). They thus form a set of $3+3+4$ poetic syllables or $3+3+5$ pulses (in which the last pulse can be an extension of the final tonic or the unstressed final atony).

The only style of verses with 11 syllables used among the cantadores is the Galope à Beira-Mar - a décima that is always concluded with a variation of the phrase "Nos dez de Galope da beira do mar" [The 10 of us go galloping by the sea]. In it, the tonic accents are placed on the second, fifth, eighth and eleventh syllable of each verse, as in this stanza improvised by Geraldo Amâncio.

Eu sei que Jesus do Céu me conhece,

Gosta do meu verso, dessa propaganda.

Se eu peço um repente, o Cristo me manda,

Me manda ligeiro, pois lá do céu desce.

Depois, na cabeça, o verso aparece,

Me desce pra boca preu pronunciar.

Inda tem um anjo para me ajudar.

E tem uma máquina nesse meu juízo:

Não faz outra coisa, só faz improviso

Nos dez de galope da beira do mar. 
I know that Jesus in Heaven knows me

Likes my verse, this propaganda.

If I ask for a repente, Christ, sends me one,

He sends it quickly, it descends from heaven.

Later, in my head, the verse appears,

Descends through the mouth for me to pronounce.

Even has an angel to help me.

And there is a machine in my judgment:

It doesn't do anything, just improvises

The ten of us gallop along the sea.

(Cantoria in Fortaleza, Ceará, 2008).

The verses link sets of $2+3+3+3$ poetic syllables, corresponding to $3+3+3+3$ pulses. They thus form four regular tempos with three pulses each, which are preferentially sung faster than the other styles usually are. In the first verse of a stanza and in those that follow "acute verses", the first pulse of the first group is a pause or the prolongation of the tonic syllable that closes the previous line. In the "low verses", the final unstressed syllable is the first pulse of the following verse as in “(ajudar)( - E tem)(uma má-)(quina nesse $\underline{\mathbf{e}}^{\mathbf{1 1}}$ )(meu juí-)(zo: Não faz)(outra coi-)(sa, só faz)(improvi-)(so Nos dez)(...).”

The Galope à Beira-Mar has a particularity that is barely noticed by singers and listeners, but for this reason is revealing of the role of the rhythmic sense in the composition of the verses. By conducting a scansion of the first verse of this stanza, it can be seen that it has only ten and not eleven poetic syllables. This is because, upon allocating the tonic syllable of an oxytone word in the third pulse of the second tempo (the fifth syllable), the same process takes place as with any acute verse in a Galope: the poets fill in the next beat with a pause or prolongation of the final strong syllable. That is, even with one less syllable, all of the pulses are realized and the rhythm remains unaltered - for this reason, few people realize this, and it was emphasized to me by two poets, who sought to deepen their understanding of the poetry by writing and scanning their stanzas and that of other authors. In addition, if the same rhythmic standards are possible, either in the fifth or in the eleventh syllables, the verse

11 It is common to see in the Galopes an unstressed syllable on the last pulse of the first or third set, as can be noted in this and in other verses of the stanza in question, a deviation that can be accommodated in the singing. Nevertheless, to sing a verse with the fifth or eleventh syllable unstressed would be an un acceptable error in meter. 
of the Galope can be described as two equal units of $2+3$ syllables or of $3+3$ pulses - an interpretation defended by some singers and scholars.

It is thus clear that the incorporated rhythm of the verse sung predominates as a practical foundation for the improvisation on the established norms of poetry. The toada is an essential cognitive device in the repente, because the singer uses it to incorporate the rhythmic standards and gain a global perception of the stanzas he composes. Therefore, the toada performs for the cantadores a function similar to that of the formula for the bards of ancient Yugoslavia although it is more important in terms of the rhythm of the poetry than for the content of the verses.

Other abilities and resources of presentation are relevant in the poetic improvisation. I emphasize "knowledge" or experience, which provide information about origin and various forms of content that the poet should accumulate to be able to use when improvising. In the cantoria, there is a strong appreciation for intellectual work opposed to physical labor (Travassos 200o), which Sérgio Buarque de Holanda (2002) recognized as predominant in Brazilian society. This respect does not imply appreciation for speculative thinking, but for the exhibition of illustration.

Nevertheless, beyond exhibition, broad experience helps the cantador open routes during the improvisation, for example, by inserting original ideas in common themes or finding something to say about uncommon themes and difficult rhymes (which offer few possibilities) imposed by a mote or deixa. Even to observe rules of cantoria, knowledge is needed about the so-called "norma culta" of the Portuguese language. In addition, given that cantoria is an agonistic art, the poet must be prepared to confront its clashes. It is important to have command of a wide range of knowledge and issues, because they can be raised by a companion, asked for by listeners or demanded at a festival.

\section{Method of composition}

In the poetic dialog, a cantador seeks to compose his stanza, or at least plan it, at the time in which his partner is presenting his verses. In addition, he first constructs the conclusion (the last two verses) of the stanza and later thinks of the middle and the beginning. Some try to compose the entire stanza during these 20 or 30 seconds that precede singing. The purpose of this is to have the end of the stanza also be the climax, because that is when the 
public pays closest attention. The bertsolariak (Basque repentistas) first think of a distinctive conclusion for the stanza, or at least for the final rhyme. This has a methodological function, because the definition of a strong idea for the ending gives greater security to the composition of the remaining portions, and has a communicative function, because the stanza is constructed in a crescendo and its peak coincides with the conclusion, startling the public. This surprise occurs because the attention of the listener is on the verses that the poet is presenting, while the attention of the poet is on the final verses (Egaña 2005: 330-1).

I exemplify this based on a stanza of João Paraibano and Sebastião Dias, sung on the mote (in seven sylables) "the more I sing of the sertão, the more I have to sing," requested by a listener at a cantoria.

\footnotetext{
João Paraibano

Lembro armadilha e quixó, ${ }^{12}$

Pássaro beliscando frutas,

Mas não esqueço das matutas

Com o rosto cheirando a pó.

Doidas pra ir pra o forró,

E o pai sem querer deixar,

Mas é perdido empatar:

Quando ele dorme, elas vão.

Quanto mais canto o sertão,

Mais tem sertão pra cantar. ${ }^{13}$
}

Reminds me of a trap and snare

A bird nibbling fruits,

But I don't forget the yokels

With face snorting dust.

Crazy to go to the dance,

And dad doesn't want to let them,

But it's impossible to break even:

When he sleeps, they go.

The more I sing of the sertão,

The more I have to sing.

12 A type of trap to catch small mammals.

13 The mote glorifies the sertão as a vast and endless theme, countering the pretension of some, who maintain that the themes of knowledge (history, mythology, geography, politics knowledge in general etc.) would be more challenging to the poets. 


\title{
Sebastião Dias
}

Quando eu canto a capoeira, O sertão é minha cara.

Canto o preá na coivara, Canto o tejo ${ }^{14}$ na carreira

E o boi, quando tem coceira

Que pega a lhe incomodar,

Para a coceira parar,

Passa a língua como a mão.

Quanto mais canto o sertão,

Mais tem sertão pra cantar.

\author{
When I sing of the capoeira ${ }^{15}$, \\ I have the face of the sertão \\ I sing of the hamster in the twigs, \\ I sing of the scampering tejo \\ And the ox, when it itches \\ That begins to bother it, \\ To stop the itching, \\ Passes its tongue like a hand. \\ The more I sing of the sertão, \\ The more I have to sing.
}

(Cantoria em Fortaleza, Ceará, 2007).

These stanzas show a very common pattern. In the first verses, the poets only evoke elements of life in the sertão, which is the broadest theme proposed by the mote. João only presents the personalities of the stanza (the matutas or hicks) in the third verse, and in the final block of four verses (in the case of the Mote, the 5 th to the 8 th verses), portrays a generational conflict with the surprising poetic image of a father sleeping, which represents the inability of old values to deal with transformations in sexual mores.

Sebastião only developed his central idea, the ox with an itch and its gesture of scratching itself in the final four lines. He then uses a recurring method of creation of images in cantoria, which is the comparison of actions of animals and phenomenon of nature with attitudes, inventions and human

\footnotetext{
14 A type of lizard (Tupinambis teguixin). The same as tejuaçu, teiú ou teiú-açu.

15 Capoeira is the first vegetation of bushes and small trees to grow after a woods or forest is cut down.
} 
attributes. This glorification of the perfection of natural processes, attributing to them human characteristics (such as the precision of the gesture of the ox when he scratches) or questioning how they occur without human intervention ( the "reverse gear" of the humming bird, the "motor" that gives movement to the stars, and the "calendar" by which some species of fauna from the sertão are able to "predict" the arrival of the rainy season, are often images used). These figures express the place of man in a cosmology according to which nature represents the perfection of divine creation, while man, imperfect and small before this magnitude, can mitigate his imperfection and impose himself on nature by means of techniques and knowledge that he builds from the divine gifts of intelligence and free will.

As a function of the redundancy of ideas that they present, the recurring themes are a base for the composition of the verses. Challenge, general knowledge, childhood, longing, mother, sertão and old age are among the most frequent, and many of them interact in the composition of the stanzas. The themes carry collectively based references about feelings and social values and serve as a route for the composition.

They perceive that improvisation is not a merely spontaneous action or one that is strictly sudden. It requires method and planning. In addition, upon improvising, the singer establishes a relationship with a set of aesthetic models and cultural references. To give meaning to the ideas, values and collective dilemmas, the poet navigates this framework, collecting images, forms of construction of thoughts and forms of expression, to rearrange them in new stanzas, in specific situations.

\section{Improvisation}

I once asked the singer Zé Maria: "what is improvisation?" He pondered the complexity of the question and responded "it is to speak without thinking." Then he thought a bit better:

It is fast, rapid reasoning, At times [singing repente], you say something without thinking, as a reflex, like a goal keeper when he defends a point blank shot. Like when you are walking and you slip and you support yourself on the other leg to not fall. And it works. But normally you think of something to say. So, improvisation is thinking rapidly. 
That is, Zé Maria speaks of improvisation as something automatic and unpremeditated. To illustrate this type of movement, he uses metaphors: of a goal keeper in relation to the other players and the ball; of a pedestrian with the force of gravity and the irregularities of the path. Then, he concludes that poetic improvisation demands an agility of thinking to formulate what is to be said in response to situations.

What has been said until now about the abilities of the repentistas allows understanding that their improvisation does not come from nowhere. Even in the act of sudden repente, "without thinking," "without planning," the rhythm incorporated to the poetry, the recurring themes, the experience, the stored associations of rhymes and ideas are resources the cantadores use for their task. In addition to requiring preparation (for example the acquisition of knowledge) and constant practice, the art of repente demands, at the time of presentation, planning for the composition of the verses. Therefore, from a practical perspective, it does not make sense to speak of pure improvisation. There is always an archive of influences, memories, thematic circles and analogous situations in relation to which the repentistas compose original texts, as Díaz-Pimienta (2001: 172) affirms about repente in Cuba. This becomes clearer if we consider improvisation in cantoria and in other contexts as relational in two senses: of an action in relation to models incorporated from art and with factors of the situation.

Thinking about the relationship between the improviser and his cognitive models, Nettl $(1974 ; 1988)$ criticizes the opposition established in Western erudite music between composition and improvisation, to the degree to which both involve the relationship of music with cognitive models of their art. He prefers to understand these two practices not as opposites, but as two poles in a continuum, distinguished by the time between creation and presentation. Nevertheless, Nettl ignores fundamental differences in the structure of the actions that he is discussing. His argument considers the improviser to be alone in relation to his techniques, with his models and with his work. But the essential distinction between what is called prior composition and improvisation (composition "in the course of performance") is not the interval of chronological time between composition and presentation. It resides in the structure of the situation peculiar to each one of these poles. That is, improvisation should respond to the imperatives of the situation, and the interactions of the moment are functions of the result. More than a composition 
in the act, in the moment, in the course of the presentation, improvisation is an interaction, an interplay of intervention and response to the act, to the moment, to the course of presentation. This can be extended to other forms of improvisation such as jazz (Becker 2000; Faulkner 2006) or the music of gamelan orchestras of Indonésia (Brinner 1995).

In other poetic arts of the Brazilian Northeast, such as the coco de embolada and maracatu rural, there is no requirement to compose stanzas at the time of the performance. But the singing of pre-composed verses must be "fit in" in response to what the partner sings and to the other actions in the presentation space - joking with spectators is common in the embolada. Thus, even the use of memorized stanzas requires a improvisational ability to insert them in the presentation.

Therefore, more than a relation with aesthetic models and standards of execution, improvisation places the subject in interaction with time, with the actions of other subjects and with other factors of the situation. Thus, the abilities needed to improvise are not previously contained in a person: they are always relative to the interactions in which the agent takes part and they are the abilities that allow the individual to be part of the order of the social dynamic. Bourdieu (1977: 10-1) speaks of a practical command of the symbolism of social interactions - something like tact, savy, savoir-faire - demanded and supposed by the interplay of sociability, which are complemented in a "spontaneous semiology" and are more similar to boxing (in which each movement triggers a counter movement) than to the hermeneutic paradigm. That is, there is a practical and not completely conscious knowledge that is essential for the continuous decodification of actions and situations, which contributes to an adjustment of practices and expressions to the reactions of the other agents.

Cantadores and listeners of cantoria value the result of the improvisation, the finished stanza, which can then be memorized and recited in other contexts or registered in an anthology. But the process also stirs fascination. It is very common for a declamation or written citation of an improvised stanza to inform at least the content or the outcome of the preceding stanza, or some motivating incident, to indicate the astuteness of the cantador, and the speed of his thinking in the poetic creation. That is, cantadores and listeners value the relational character of poetic improvisation. A poet is respected for his capacity to create "great verses" and mainly for his ability to create them in response to the stimuli of the situation. 
In repente, the cantador is placed in relation to the rules of the cantoria, with the incorporated rhythm of the poetry, with values and ideas encompassed by the recurring themes, with musical models, with knowledge and values about various issues, and with the action of the others present in the cantoria. Their abilities can be understood as competencies for the interactive game of poetic improvisation, in which verses must be created "immediately", "de repente" [suddenly]. More than this, the value of the stanzas goes beyond their linguistic content, because they constitute actions in dialog with what occurs in that situation.

\section{Bibliography}

AYALA, Maria Ignez Novais. 1988. No arranco do grito: aspectos da cantoria nordestina. São Paulo: Ática.

BECKER, Howard S. 2000. "The etiquette of improvisation". Mind, Culture, and Activity, 7(3): 171-176.

BOURDIEU, Pierre. 1977. Outline of a theory of practice. Cambridge: Cambridge University Press.

BRINNER, Benjamin. 1995. Knowing music, making music: javanese gamelan and the theory of musical competence and interaction. Chicago: Chicago University Press.

BUARQUE DE HOLANDA, Sérgio. 2002 [1936]. Raizes do Brasil. In: S. Santiago (coord.), Intérpretes do Brasil vol. 3. Rio de Janeiro: Nova Aguilar. pp. 890-1102. CROOK, Larry. 2005. Brazilian music: northeastern traditions and heartbeat of a modern nation. Santa Barbara, CA / Denver, CO / Oxford: ABC-Clio.

DÍAZ-PIMIENTA, Alexis. 2001. Teoría de la improvisación: primeras páginas para el estudio del repentismo. Habana: Unión de Escritores y Artistas de Cuba. EGAÑA, Andoni. 2005. "The process of improvised bertsoak". In: S. Armistead; J. Zulaika (eds.), Voicing the moment: improvised oral poetry and Basque tradition. Reno, NV: University of Nevada, Center for Basque Studies. pp. 323-240.

FAULKNER, Robert S. 2006. "Shedding culture”. In: H. S. Becker; R. Faulkner; B. Kirshenblatt-Gimblet (orgs.), Art from start to finish:jazz, painting, writing, and other improvisations. Chicago/ London: The University of Chicago Press. pp. 92-117.

FINNEGAN, Ruth. 1988. Literacy and orality: studies in the technology of 
communication. Oxford: Basil Blackwell.

GONÇALVES, Marco Antonio. 2007. “Cordel híbrido, contemporâneo e cosmopolita”. Textos Escolhidos de Cultura e Arte Populares, 4(1):21-38.

INGOLD, Tim; HALLAM, Elizabeth. 2007. "Creativity and cultural improvisation”. In: E. Hallam; T. Ingold (eds.), Criativity and cultural improvisation. Oxford/ New York: Berg. pp. 1-24.

JAKOBSON, Roman. 1966. "Grammatical parallelism and its russian facet". Language, 42(2): 399-429.

JAKOBSON, Roman. 1975. Linguística e comunicação. São Paulo: Cultrix.

KUBIK, Gerhard. 1979. "Pattern perception and recognition in african music". In: J. Blacking; J. Kealiinohomoku (eds.), Performing arts: music and dance. The Hague: Mouton. pp. 221-249.

LORD, Albert Bates. 2000 [1960]. The singer of the tales. Cambridge, MA: Harvard University Press.

MAGRINI, Tullia. 1998. "Improvisation and group interaction in italian lyrical singing". In: B. Nettl; M. Russell (eds.), In the course of performance: studies in the musical improvisation. Chicago: University of Chicago Press. pp. 169-198.

NETTL, Bruno. 1974. "Thoughts on improvisation: a comparative approach". The Musical Quarterly, 6o(1): 1-19.

NETTL, Bruno. 1998. "Introduction: an art neglect in scholarship. In: B. Nettl; M. Russell (orgs.), In the course of performance: studies in the musical improvisation. Chicago: University of Chicago Press. pp. 1-23.

OliveirA, Luciano Py de. 1999. A música na cantoria em Campina Grande $(P B)$ : estilo musical dos principais gêneros poéticos. Dissertação de Mestrado, Universidade Federal da Bahia - Salvador.

RAMALHO, Elba Braga. 2001. Cantoria nordestina: proposta de um novo enredo para o metro cantado. Tese de Professor Titular, Universidade Estadual do Ceará - Fortaleza.

SAUTCHUK, João Miguel M. 2009. A poética do improviso: prática e habilidade no repente nordestino. Tese de Doutorado, Universidade de Brasilia - Brasília. SEEGER, Anthony. 2004 [1987]. Why Suyá sing: a musical anthropology of an amazonian people. Urbana/ Chicago: University of Illinois Press.

SUTTON, R. Anderson. 1998. “Do javanese gamelan musicians really improvise?”. In: B. Nettl; M. Russell (orgs.), In the course of performance: studies in the musical improvisation. Chicago: University of Chicago Press. pp. 69-92. TAM BIAH, Stanley Jeyaraja. 1985. "A performative approach to ritual". In: 
Culture, thought and social action. Cambridge, MA: Harvard University Press. pp. 123-166.

TAYLOR, Charles. 1993. “To follow a rule...”. In: C. Calhoun, E. Lipuma, M. Postone (eds.), Bourdieu: critical perspectives. Chicago: The University of Chicago Press. pp. 45-6o.

TRAVASSOS, Elisabeth. 1989. "Melodias para a improvisação poética no Nordeste: toadas de sextilhas segundo a apreciação dos cantadores”. Revista Brasileira de Música, XVIII: 115-129.

TRAVASSOS, Elisabeth. 1999. "Repente e música popular: a autoria em debate”. Brasiliana, 1:6-15.

TRAVASSOS, Elisabeth. 2000. "Ethics in the sung duels of north-eastern Brazil: collective memory and contemporary pratice". British Journal of Ethnomusicology, 9(1):61-94.

WHITE, Linda. 2005. "Formulas in the mind: a preliminary examination to determine if oral formulaic theory may be applied to the Basque case". In: S. Armistead; J. Zulaika (eds.), Voicing the moment: improvised oral poetry and basque tradition. Reno, NV: University of Nevada, Center for Basque Studies. pp. 265-280.

zÉ MARIA DE FORTALEZA (JosÉ MARIA do NASCimento). 2006. Curso prático de literatura de cordel. Fortaleza: mimeo.

\section{About the author}

João Miguel Manzolillo Sautchuk

Doutor em Antropologia pela Universidade de Brasília, 2009.

Professor Adjunto do Departamento de Ciências Sociais / Universidade Federal do Piauí

Professor Colaborador do Programa de Pós-Graduação em Antropologia e Arqueologia/ Universidade Federal do Piauí

Endereço: Av. Vilmary, no 2416 apto 1502

Bairro São Cristóvão - Teresina - Piauí - CEP 64051-902

Telefones: (86) 99399833 / 3233-9458 (res) / 3215-5780 (UFPI)

E-mails: joaomiguel@ufpi.edu.br - msjoaomiguel@gmail.com 